IZA DP No. 9221

Sources of the Union Wage Gap:

Results from High-Dimensional Fixed Effects

Regression Models

John T. Addison

Pedro Portugal

Hugo Vilares

July 2015 


\title{
Sources of the Union Wage Gap: Results from High-Dimensional Fixed Effects Regression Models
}

\author{
John T. Addison \\ Durham University Business School, University of South Carolina, and IZA \\ Pedro Portugal \\ Banco de Portugal, Nova School of Business and Economics, and IZA \\ Hugo Vilares \\ Banco de Portugal
}

Discussion Paper No. 9221
July 2015

IZA

P.O. Box 7240

53072 Bonn

Germany

Phone: +49-228-3894-0

Fax: +49-228-3894-180

E-mail: iza@iza.org

Any opinions expressed here are those of the author(s) and not those of IZA. Research published in this series may include views on policy, but the institute itself takes no institutional policy positions. The IZA research network is committed to the IZA Guiding Principles of Research Integrity.

The Institute for the Study of Labor (IZA) in Bonn is a local and virtual international research center and a place of communication between science, politics and business. IZA is an independent nonprofit organization supported by Deutsche Post Foundation. The center is associated with the University of Bonn and offers a stimulating research environment through its international network, workshops and conferences, data service, project support, research visits and doctoral program. IZA engages in (i) original and internationally competitive research in all fields of labor economics, (ii) development of policy concepts, and (iii) dissemination of research results and concepts to the interested public.

IZA Discussion Papers often represent preliminary work and are circulated to encourage discussion. Citation of such a paper should account for its provisional character. A revised version may be available directly from the author. 


\section{ABSTRACT \\ Sources of the Union Wage Gap: Results from
High-Dimensional Fixed Effects Regression Models}

This paper provides estimates of the union wage gap in Portugal, a nation until recently lacking independent data on union density at firm level. Having estimated nonlinear and linear estimates of the effect of union density on the wage gap, the next stage of the analysis seeks to account for the influence of worker, firm, and job-title permanent heterogeneity, using a three high dimensional fixed effects strategy. Gelbach's decomposition is used to determine the role of each as sources of the union wage gap. A generalization of this technique is applied for the nonlinear case. We find evidence of a substantial union wage gap in circumstances where the majority of the workforce is organized. There is also some clear indication of substitution effects among different types of compensation that favor of wage supplements (likely reflecting tax considerations) as bargaining power increases. The principal result of the decomposition exercise at the most aggregate level is that the union wage gap is mainly manifested through a firm fixed effect, suggesting that unions may force firms to reposition themselves as far as their wage compensation policies are concerned. A subsidiary result is that matching plays almost no role. More importantly, however, are the results obtained when a distinction is drawn between the (estimated) bargained wage and total earnings. Rising union density has a much greater influence upon the former and is negatively related to the difference between the two. This result is consistent with a wider literature indicating that firms have a 'wage cushion' enabling them to avoid some of the strictures of unionism bargaining power.

JEL Classification: J31, J33, J41, J51, J52

Keywords: union density, union wage gap, total compensation, bargained wages, wage cushion, wage supplements, worker/firm/job title fixed effects, Gelbach decomposition

Corresponding author:

John T. Addison

Department of Economics

Darla Moore School of Business

University of South Carolina

1014 Greene Street

Columbia, SC 29208

USA

E-mail: ecceaddi@moore.sc.edu 


\section{Introduction}

This paper provides estimates of the union wage gap in Portugal, a nation until recently lacking independent data on union density at firm level, and proceeds to decompose that gap in terms of the contribution of worker, firm, and job title heterogeneity. Estimation therefore proceeds in two main stages. In the first, possessing data on the share of workers organized - if not on any individual worker's union status - a union density-specific fixed effects model is estimated for individual earnings, where the fixed effect represents a different intercept in each worker's wage equation. Then, in a second step, a kernel regression is computed allowing for a nonlinear functional form of the effect of union density on wages. Results are also presented for a linear version of the model.

The next stage of the analysis considers the contribution of the productivity of workers, their occupational distribution, and the compensation policies and human resource strategies of firms to the wage gap. Specifically, it accommodates worker, firm, and job-title permanent heterogeneity, using a three high dimensional fixed effects strategy, and then uses Gelbach’s (2016) decomposition to determine the role of each as sources of the union wage gap. Specifically, the difference between the density coefficient in a base earnings function model excluding the three fixed effects and the corresponding coefficient in a regression including them is given by the coefficients on union density in separate regressions of the respective fixed effect on the arguments of the base model. For the nonlinear case, linking the union premium to the extent of worker representation, a generalization of the Gelbach composition is applied and summarized in three curves charting the contribution of the three fixed effects.

We find evidence of a substantial union wage gap of around 15.8 percent when the majority of workers is organized that is either on a par with or exceeds U.S estimates, ${ }^{1}$ despite the generalization of wage settlements through extension procedures to virtually the entire labor force. But there is every indication of nonlinearities in the wage gap, a failure to account for which imparts material upward bias to the measure. There is also some clear indication of substitution effects among different types of compensation that favor of wage supplements (as opposed to components linked to working time) as bargaining power increases. The main result of the decomposition exercise for actual/total earnings is that the union wage gap is mainly manifested through a firm fixed effect, suggesting that unions may force firms to reposition themselves as far as their wage compensation policies are concerned. There is also some evidence of a job title effect or 'occupation premium' having to do with the position held by the union worker in the firm. Yet even though unionized firms have higher job titles on average, the evidence of systematic upgrading of union workers in the compensation tables is muted. That said, job title effects are stronger than worker quality. Union workers are of only marginally higher unobserved and observed

\footnotetext{
${ }^{1}$ See the early studies of Blanchflower and Bryson (2003), and Hirsch (2004); and, especially, the more recent plant-level studies of Frandsen (2012), and Lee and Mas (2012).
} 
permanent quality than their nonunion counterparts. One further result is of interest for the actual earnings measure: our analysis reports minimal influence on the wage gap stemming from the quality of the job match, namely the matching of higher quality workers with more productive firms. That is, a 'combined' worker and firm fixed effect also capturing the interaction between these two effects explains little more of the union wage gap than do their separate contributions.

Developments in the wider earnings determination literature suggest that a distinction might usefully be drawn between actual earnings and the bargained wage. The latter is not directly observed in the datasets used in this inquiry. Drawing on research by one of the present authors, however, estimates of the latter can be derived from the distribution of base wage rates for which we do have information. A rather different set of results are obtained when Gelbach decompositions of the bargained wage, and of the so-called wage cushion - the difference between the current actual wage and the ruling contractual wage (set for each worker in a collective agreement) - are implemented. In the first place, union density is more strongly related to the bargained wage than is the case for actual earnings. Here, by construction, the principal vehicle is the job title fixed effect, with only a small role now being played by firm (and worker) fixed effects. In the second place, decomposition of the wage cushion suggests that firms may seek to compensate for elevated job titles by reducing the wage cushion, although they are constrained by union power in this regard. This evidence comports with findings in the literature to the effect that the wage cushion partly offsets or dilutes the impact of collective (Cardoso and Portugal, 2005).

The plan of the paper is as follows. To set the scene, section II outlines the machinery of collective bargaining in Portugal. Section III describes the unique datasets used in this inquiry. The modeling strategy is carefully outlined in section IV prior to the presentation of the detailed empirical results in Section V. Section VI contains the results of several robustness checks. A brief summary concludes.

\section{The Bargaining Framework}

Portuguese law makes provision for three types of collective bargaining at national, regional, and local level. First, there is firm-level bargaining between an individual company and one or more unions. These so-called Acordos de Empresa (or AEs) are important in the oil sector and transport and communications. Second, there are collective agreements signed by several employers that are not part of an employers' association and one or more trade unions, known as Acordos Colectivos de Trabalho (or ACTs), that are significant in the financial sector and utilities. However, it is industry-level/branch or sectoral agreements, so-called Contratos Colectivos de Trabalho (CCTs), negotiated between one of more employers' associations and one or more unions, that predominate. CCTs in conjunction with extension agreements (described below) that are very largely based on them explain levels of collective bargaining coverage in 
the order of 90 percent of workers when union density approximates 11 percent (see Addison, Portugal, and Vilares, 2015). The vast majority of agreements are signed by unions linked to the two major union confederations: the CGPT-IN or General Confederation of Portuguese Workers, and the UGT or General Workers' Union. The gaps in coverage are largely in personal and other services, and in public administration where, despite centralized negotiations between the government and the trade unions, wages are decided upon unilaterally by the government. The wages of employees in publicly-controlled companies, such as public transportation and the postal service, are collectively bargained in the normal way.

The industry-level or sectoral agreements may cover a range of industry-specific occupations but as the system does not rule out parallelism or overlapping collective agreements a single enterprise may be covered by two or more agreements depending on the union affiliation of the workers (although as a practical matter the content of most of the agreements is similar, the respective tables of wages tending to be the same). The situation may be further stratified if the firm in question straddles more than one line of economic activity, thereby belonging to one or more employer associations. As a result of fragmentation, therefore, several agreements may coexist for the same region, occupation, and firm. Horizontal or occupation-based agreements are also possible, although they are infrequent largely because the law gives precedence to vertical sectoral agreements many of which are signed by a large number of primary unions that may include occupation-based unions.

Portuguese collective agreements are at once both extensive and general. They are extensive insofar as they cover many categories of worker. On average branch agreements have historically set wages for around 100 job titles, or categoria profissional. However, the contents are general. Thus, for example, agreements set wage floors and make no attempt to anticipate earnings growth beyond that set by collective bargaining and incorporate such development within the contract (as in countries such as Sweden). As a result, the links between wage growth in Portuguese contracts and the actual economic conditions obtaining at firm level can be very loose, giving the firm freedom of maneuver to tailor remuneration according to its prevailing economic circumstances. Other research has exploited this difference between actual wages and the contract wage - termed the 'wage cushion' - to offer an explanation for considerable wage flexibility (and low unemployment) in the past despite institutional structures that prima facie might be expected to impart rigidity (see, in particular, Cardoso and Portugal, 2005). In analyzing the role of union density on wages, therefore, our own analysis will reflect not only actual wages but also the (estimated) contractually bargained wage and the difference between the two (the wage gap). In addition, since Portuguese contracts set other minimum conditions apart from the basic monthly wage level - most typically, allowances for meals, overtime, shifts, and bonuses not having a 
basis in productivity - our analysis will also investigate the impact of union density on these other components of actual earnings as well. ${ }^{2}$

The most potent mechanism shaping the formation of wages has traditionally been the systematic extension via so-called Portarias de Extensão of industry-wide agreements (and occasionally ACTs) by the Ministry of Employment, following a request from either or both of the parties to the agreement. (Voluntary extensions are also possible, while employers who sign an agreement with a trade union(s) usually extend its application to the entire workforce, irrespective of the worker's union status.) The upshot of this near automatic procedure is that even those wage agreements reached by trade unions and employers' associations with very low representation have had a strong impact in setting wage floors. As indicated earlier, between 70 and 80 percent of the labor force have benefitted from collective agreements without being members of the organizations that signed them. Finally, in the absence of one of the representatives, or in the presence of strategic delays in negotiations/refusals to negotiate, the Ministry of Employment can regulate the sector directly through an Ordinance of Working Conditions, or Portarias de Condições de Trabalho. (An arbitration process, either mandatory or voluntary, may be set in motion to unfreeze 'blockages.') The extension mechanism in conjunction with the large number of job titles set down in the typical sectoral agreement together explain the 30,000 (informal) minimum wages referred to in the title of a very recent analysis of the employment and wage consequences of collective bargaining extensions (Martins, 2014). In addition to the extension procedure, wage floors are also set under national minimum wage machinery, set up in 1974. The minimum wage can exceed that set under sectoral bargaining. This guaranteed monthly minimum wage or Retribuição Mínima Mensal Garantida (RMMG) was virtually stagnant in real terms between 2002 and 2006, leading to an agreement between the social partners (government, the trade union confederations, and the employers' confederation) ${ }^{3}$ in 2006 allowing for an increase of almost 30 percent, to be phased in over five years and setting a medium-term target value $€ 500$ by 2011. It has been estimated that the share of minimum wage earners among full-time workers aged 18 to 61 years rose dramatically from 6.7 percent of total employment in 2006 to 16.6 percent in 2010 (Carneiro, Guimarães, and Portugal, 2012: 451).

\footnotetext{
${ }^{2}$ Until recently, it has been the case that Portuguese collective agreements remain in place until a new agreement is signed. Coupled with the favor laboris principle that new agreements should yield more favorable conditions that those they are replacing, this has meant that collective agreements have tended to be revised regularly (and typically on an annual basis) only insofar as wages are concerned, their other terms and conditions often being left untouched for many years. Recent changes in the Portuguese labor code mean that collective agreements can now expire if they are not renewed, although the expiry period is protracted.

${ }^{3}$ Although the last centralized agreement or pact establishing (a reference value for) nation-wide wage increases was in 1996, a number of agreements have been reached in the tripartite Standing Council for Social Concertation, or Comissão Permanente da Concertação Social. On the path of social concertation in Portugal, see Palma Ramalho (2013).
} 
As is well known, Portugal was subject to a severe economic crisis in 2011/2013. Both systems of minimum wages - nation-wide and collectively bargained/extended - were disrupted by the crisis. As part of the Memorandum of Understanding ${ }^{4}$ concluded between the Portuguese government and the Troika in May 2011, it was agreed among other things that the procedures for extending collective agreements would be changed, even prior to which the government committed to restrict the extension of collective agreements. ${ }^{5}$ In October 2012 the government announced new criteria for the administrative extension of collective agreements taking into account the representativeness of the negotiating organizations and the implication of such extension for non-affiliated firms. Most importantly, agreements could only be extended if at least one union and one employers' organization requested it and the wider signatory organizations employed more than one-half of the employees in the relevant industry. However, in June 2014 this Resolution was modified: the criterion is now that the employers' association represents at least 50 percent of employees in the sector, or that its associates must include at least 30 percent of micro, small, and medium companies (employing up to 250 employees). As far as the national minimum wage was concerned, the Memorandum proposed to make any increase in the minimum wage conditional on economic and labor market developments. The minimum wage was duly frozen and in 2012 and 2013 it stood at the level of 2011 (viz. €485). It was not uprated to €505 - a little above the medium-term target until October 2014.

Our sample period covers this period of economic crisis, which has been credited with a pronounced downturn in collective agreements ${ }^{6}$ and even a radical decentralization of collective bargaining (see EurWORK, 2013, 2014; Schulten, 2013; Schulten and Müller, 2013). While recent research indicates that the death of Portuguese collective bargaining have greatly been exaggerated by outside observers, our own analysis will offer robustness checks that look specifically to the 2010-2013 period.

\footnotetext{
${ }^{4}$ The terms of the Memorandum are available at http://economico.sapo.pt/public/uploads/memorandotroika_0405-2011.pdf.

${ }^{5}$ Other changes under the Memorandum were revisions to the unemployment insurance system in terms of the level and duration of benefits, a diminution in employment protection via a reduction in severance payments and the relaxation of protection against individual dismissals, a reduction in the payment for overtime working and an increase in hours by reducing compensatory time off per hour of overtime, and an expansion of flexible working time arrangements in the form of working time accounts at individual and plant level.

${ }^{6}$ For an economic explanation of the reduction in new CCTs and extension ordinances - but not in the number of workers covered by new and existing agreements - see Addison, Portugal, and Vilares (2015).
} 


\section{The Datasets}

The data sources used in this exercise are the Quadros de Pessoal (Personnel Tables), 1986-2009, and the Relatório Único (Single Report), 2010-2013. ${ }^{7}$ Each longitudinal matched employer-employee-job title database is identical other than in one main respect: the successor survey contains data on the union density of the firm that for the first time permit accurate estimates of union density to be obtained.

Beginning with the Quadros de Pessoal, the survey is mandatory in nature and is administered by the Ministry of Employment and Social Security on an annual basis for all establishments with at least one wage earner. All workers employed by the firm in the reference month (March of each year until 1993, October thereafter) are reported, although civil servants and workers in domestic service are not covered while the coverage of agriculture is necessarily spotty because of the low share of wage earners in that sector. In short, the entire population of private-sector firms in manufacturing and services with wage earners is covered. Further, by virtue of its mandatory nature, the high response rate in the Quadros de Pessoal ensures that problems commonly associated with panel data are much attenuated. This is underscored by the requirement that the data be made publicly available to every worker at the place of work.

The dataset reports the firm's location, industry, employment, sales, ownership, and legal basis. Worker information includes gender, age, skill, broad occupation, schooling completed, starting date with the firm, earnings, and working hours. In addition, the survey also records the form of collective bargaining arrangement and the specific job title held by the worker under collective bargaining. ${ }^{8}$ The wage variable is recorded in considerable detail, indicating the worker's gross monthly earnings (the actual or total wage), which sum is split into the following four components: the base wage (i.e. the gross pay for normal hours of work), overtime pay, and regularly and irregularly paid supplements. Normal monthly hours worked and overtime hours are also reported. Note that for the year 2010 alone, an upgraded version of the dataset distinguishes between the three regularly paid supplements, namely the meals subsidy, shift pay, and other benefits not attached to productivity assessments.

The following restrictions were placed on the data. First, the analysis was confined to full-time employed workers in receipt of what was contractually defined for the reporting month. Second, workers from the agriculture, fisheries, and energy products/extraction sectors were excluded. Third, workers aged less than 18 years and greater than 65 years were excised, as also were those whose monthly wages were less than 80 percent of the mandatory minimum wage (or $R M M G$ ), corresponding to the lowest

\footnotetext{
${ }^{7}$ For the years 1990 and 2001 the Quadros de Pessoal database was not administered.

${ }^{8}$ Those workers not covered by any collective agreement are coded as such (i.e. "non-covered workers"). According to Addison, Portugal, and Vilares (2015), they comprise less than 10 percent of the sample between 2010 and 2013,
} 
admissible wage for apprentices. Finally, observations not belonging to the largest connected group were dropped, amounting to some 1 percent of the total number of observations. ${ }^{9}$

This brings us to the successor Relatório Único, initiated in 2010 and ending with the recently made available 2013 wave. As in the later versions of Quadros de Pessoal, the database is collected in October of each year. As noted earlier, the key feature of this successor dataset is that it allows us to construct a measure of union density at firm level. Specifically, the survey asks of the manager respondent: "Indicate the number of workers for whom you have knowledge of their membership in a union (because they are union officials, because you deduct membership dues from their salary, or because the worker informed you about his/her membership so as to determine which particular collective regulation is applicable to their case)." The sum total of such workers - whose individual union membership identity is unknown, so that we cannot deploy an individual union membership variable divided by the number of workers employed by the firm provides our measure of union density.

Overall, the joint dataset includes 34,817,649 observations of worker-year pairs, of which 7,652,890 are from the Relatório Único. The joint dataset has a basis in the records of 6,620,991 workers, 732,293 firms, and 142,337 job-titles that were followed since 1986. The contribution of the Relatório Único to this total was 2,161,263 workers, 107,064 firms, and 41,684 job-titles, followed between 2010 and 2013.

\section{Modeling}

We next describe the procedures used, firstly, to estimate the union wage gap and, secondly, to account for the component contributions of firm compensation policies, worker ability, and occupation premiums via the estimation of firm, worker, and job title fixed effects, respectively.

\section{Estimation of the Union Wage Gap}

The method used to estimate the union wage gap has two steps. The first estimates a specific intercept for each level of union density. The second offers a (non-linear) semi-parametric treatment of those estimates.

In the first step we estimate a standard Mincerian wage equation, augmented by a union density fixed effect. Thus, the model can be expressed as:

$$
y_{i, t}=\boldsymbol{x}_{\boldsymbol{i}, t}^{\prime} \boldsymbol{\beta}+\vartheta_{u}+\delta_{t}+\varepsilon_{i, t},
$$

\footnotetext{
${ }^{9}$ A connected group exists when at least one element of a worker, job title, and firm links the rest of the group (see Guimarães and Portugal, 2010).
} 
where $y_{i, t}$ is worker compensation, ${ }^{10} \boldsymbol{x}_{\boldsymbol{i}, \boldsymbol{t}}^{\prime}$ is a vector of $k$ observed characteristics of the worker and his/her employer, $\boldsymbol{\beta}$ is a vector of coefficients for the observed characteristics of workers and firms, $\vartheta_{u}$ is a union density fixed effect, $\delta_{t}$ is a set of year dummies, and $\varepsilon$ is the error component. The explanatory variables (or observed characteristics) of workers and firms are age, age squared, seniority, seniority squared, and dummies for education, firm size, industry, and time.

According to equation (1), there are four factors that explain compensation variation:

1. the observed characteristics of workers and firms $\left(\boldsymbol{x}_{\boldsymbol{i}, \boldsymbol{t}}^{\prime}\right)$;

2. a fixed effect for each level of union density at firm level $\left(\vartheta_{u}\right)$;

3. a time fixed effect $\left(\delta_{t}\right)$; and,

4. a disturbance term $\left(\varepsilon_{i, t}\right)$ that is assumed to have the usual properties.

Equation (1) can thus be interpreted as the conditional expectation of compensation of a given worker, accounting for the observed characteristics of his/her employer, the worker's own observed characteristics, and the level of union density at firm level. In this approach, the number of parameters to be estimated is $k+T+U$, as we are considering all the specific intercepts for each level of union density (U).

In the second step, we will estimate a kernel regression linking the estimates of the union density fixed effect and actual union density at firm level:

$$
\widehat{\vartheta_{u}}=\mathcal{F}\left(U d_{f}\right)+v_{f, u},
$$

where $\hat{\vartheta}_{u}$ is the union density fixed effect estimate obtained from the first step, $U d_{f}$ is the prevailing union density of the firm, $v_{f, u}$ is the disturbance term, and $\mathcal{F}(\cdot)$ is a standard Epanechnikov kernel function. ${ }^{11}$

The estimation of local weighted union wage gaps results in a smoothed, nonlinear, and semiparametric estimate of a union wage gap curve. To facilitate the interpretation of the results, a convenient normalization requires that the average fixed effect in the case of absent unionization be set equal to zero.

10 Several types of compensation will be considered: total gross real compensation, bargained gross real compensation, and the wage cushion. In addition, specific components of total gross real compensation are also examined.

${ }^{11}$ According to the standard methodology of the Kernel function, the Epanechnikov kernel function can be described as:

$$
\mathcal{F}(z)=\frac{1}{2 N h^{*}} \sum_{i=1}^{N} \frac{3}{4}\left[\left(1-\left(\frac{z_{i}-z_{0}}{h}\right)^{2}\right) \times \mathbf{1}\left(\left|\frac{z_{i}-z_{0}}{h}\right|<1\right)\right], \mathbf{1}(A)=\left\{\begin{array}{lc}
1 & \text { if A occurs } \\
0 & \text { otherwise }
\end{array}\right.
$$

where $N$ is the number of workers in the sample, and $h^{*}$ is Silverman's plug-in estimate. Note that we have considered a transformation of the Epanechnikov kernel function to account for the doubling of Silverman's plugin estimate. A discussion of the classical tension between the potential bias and the smoothness of the curve is presented in Cameron and Trivedi (2005). These authors also show that the choice of the particular kernel function does not significantly alter the results. 
This assumption implies no further restriction as the union wage gap represents the relative difference in wages for workers at firms with different levels of union density, controlling for the observed characteristics of workers and firms $\left(\boldsymbol{x}_{i, t}^{\prime}\right)$.

The estimate $\widehat{\vartheta_{u}}$ represents a different intercept in each worker's wage equation. Thus, in the second step of the procedure, we shall allow firms to contribute to the kernel function via their number of workers so that each firm carries implicitly a different weight in the estimation according to its size. This is particularly useful in accounting for compositional issues of the workforce. In other words, because the estimation procedure is conducted at the worker level we are properly weighting the size of the workforce.

Moreover, proper estimation of the model requires high density panel data so as to avoid having segments of the finally estimated curve that are heavily dependent on the sparsity generated by a small number of firms, especially in circumstances where - as in the Portuguese case - the distribution of firms by level of unionization is highly asymmetric (see Addison, Portugal, and Vilares, 2015). In fact, in covering the entire population of employees and private sector firms, the estimates in the first step are not captive to large neighborhoods of union densities lacking firm observations.

Concurrently, a simplified version of this model can be estimated by OLS using a standard OLS approach in which a single slope for the effect of union density replaces specific intercepts for each level of union density, as follows:

$$
y_{i, t}=\boldsymbol{x}_{i, t}^{\prime} \boldsymbol{\beta}+U d_{f} \gamma+\delta_{t}+\varepsilon_{i, t},
$$

where $U d_{f}$ is the level of union density of the employer, and $\gamma$ is the coefficient associated with the level of union density. As a means of benchmarking, and as a way of demonstrating the usefulness of the model proposed, this benchmark model will form a starting point in what follows.

\section{Estimation of the Sources of the Union Wage Gap}

Given the estimate of the union wage gap $\left(\widehat{\vartheta_{u}}\right)$, it is useful to decompose this outcome measure into its constituent mechanisms, namely to identify the contributions of worker, firm, and job-title time-invariant heterogeneity. To this end, we adopt the conditional decomposition of Gelbach (2014).

For purposes of benchmarking, we provide the decomposition for the standard OLS approach. Thus, as a full-specification model, we include in equation (3) the sources of time-invariant heterogeneity - namely, the worker fixed effect $\left(\alpha_{i}\right)$, the firm fixed effect $\left(\lambda_{f}\right)$, and the job-title fixed effect $\left(\theta_{j}\right)$ exploiting the methodology first introduced in Carneiro, Guimarães, and Portugal (2012). ${ }^{12}$ The model thus becomes:

\footnotetext{
12 In our empirical setup, union density is observed for the years subsequent to 2009. Therefore, in order to estimate the fixed effects taking advantage of the entire time-span of the dataset (1986-2013), we estimated an
} 


$$
y_{i, t}=\boldsymbol{x}_{i, t}^{\prime} \widetilde{\boldsymbol{\beta}}+U d_{f} \tilde{\gamma}+\alpha_{i}+\lambda_{f}+\theta_{j}+\delta_{t}+\varepsilon_{i, t} .
$$

Following Gelbach (2016), consider equation (3) as the base model, whose union wage gap we intend to decompose, and take as the full specification the model in equation (4). It is shown that the difference between the coefficients in the base and full models is given by:

$$
\widehat{\boldsymbol{\beta}}-\widehat{\widetilde{\boldsymbol{\beta}}}=\mathbb{P}_{\mathbf{X}} \widehat{\boldsymbol{\beta}_{\boldsymbol{\alpha}}}+\mathbb{P}_{\mathbf{X}} \widehat{\boldsymbol{\beta}_{\lambda}}+\mathbb{P}_{\mathbf{X}} \widehat{\boldsymbol{\beta}}_{\boldsymbol{\theta}},
$$

where $\mathbb{P}_{\mathbf{X}}=\left(\mathbf{X}^{\prime} \mathbf{X}\right)^{-\mathbf{1}} \mathbf{X}^{\prime}$. This implies that the terms on the right-hand side of equation (5) are the coefficients of three regressions that regress the estimate of the pertinent fixed effect on the controls of equation (3). Focusing on the coefficients attaching to the union density variable, we have:

$$
\hat{\gamma}-\widehat{\tilde{\gamma}}=\widehat{\gamma_{\alpha}}+\widehat{\gamma_{\lambda}}+\widehat{\gamma_{\theta}}
$$

which yields an unambiguous and conditional decomposition of the union wage gap into its worker, firm, and job-title time-invariant components.

Similarly, we can apply the same principle of the Gelbach decomposition to the union wage gap curve obtained in equation (1). For that purpose, consider equation (1) as the base model, and its expansion to incorporate the fixed effects as the full specification. ${ }^{13}$ Accordingly, the latter can be written:

$$
y_{i, t}=\boldsymbol{x}_{i, t}^{\prime} \widetilde{\boldsymbol{\beta}}+\widetilde{\vartheta_{u}}+\alpha_{i}+\lambda_{f}+\theta_{j}+\delta_{t}+\varepsilon_{i, t}
$$

Analogously to the result obtained in equations (5) and (6), we verify that the difference between the union density fixed effect of the full and base models (equations (1) and (7), respectively) can be decomposed into three fixed effects; obtained by estimating three auxiliary fixed effect models where the worker, firm, and job-title fixed effects become the independent variables and the regressors match those of the base model, as follows:

$$
\hat{\vartheta}-\hat{\tilde{\vartheta}}=\widehat{\vartheta_{\alpha}}+\widehat{\vartheta_{\lambda}}+\widehat{\vartheta_{\theta}}
$$

In short, not only are we able to unambiguously decompose the union density fixed effect but also the union wage gap curve as well.

auxiliary regression from which the worker, firm, and job-title fixed effect estimates were obtained and later introduced in to equation (4). In this auxiliary regression, the union density control was absent. The estimation of the decomposition of Gelbach without the use of this auxiliary regression is performed in the robustness section, below, for the years 2010-2013.

${ }^{13}$ Following the same reasoning as presented above, an auxiliary regression was used to estimate the worker, firm, and job-title fixed effects. In the robustness section, for the years 2010-2013, the methodology is applied in a one step procedure where the worker, firm and job-title fixed effects and the union density impacts are jointly estimated. 


\section{Main Findings}

\section{The Union Wage Gap Curve for Total Earnings}

Table 1 contains full results of estimating the union wage gap in Portugal following the OLS approach described in equation (3). That gap is some 15.3 percent $\left[\left(e^{0.142}-1\right) .100\right]$, which is indicative of a sizable union wage differential after controlling for observed worker and firm characteristics.

(Table 1 near here)

This wage differential is to be interpreted in the following way: it represents the wage difference/gap between two identical workers, one of whom is employed in a fully unionized firm and the other in an otherwise identical non-unionized firm. Moreover, this methodology implies that the value of the union wage gap for each point in the continuum of union density is determined by and conforms to a linear relationship. However, an important issue is whether the marginal change in the union wage gap is in fact the same when a newly unionized worker joins a union-free workforce as opposed to one in which a large plurality of workers are organized. In seeking to estimate a union wage gap without assuming constant marginal effects throughout, we shall follow the methodology described earlier to estimate the union wage gap curve. This estimate is shown in Figure 1. It demonstrates that the linear approach is misleading. In particular, unions need some critical mass (of unionized workers) in order to influence wages materially. That is to say, only above some threshold - slightly in excess of 20 percent - do higher levels of unionism feed through into increasing union wage gaps. The premium peaks at approximately 20 percent for levels of unionization of around 70 percent, after which point we observe a modest decline.

(Figure 1 near here)

A plausible explanation for the shape of the fitted curve relies on the idea that the bargaining power of a union is a function of its ability to credibly threaten the employer through a withdrawal of labor (e.g. Farber, 1986). Moreover, conventional models of the union depict the union objective as one of seeking to increase wages (or the firm's payroll) subject to maintaining the firm intact or its being able to earn some minimum acceptable profit level. It is reasonable to assume that unions need some minimum complement of unionized workers to effectively impose costs on the employer in the event of a failure to agree. With a preponderance of the workforce organized, the capability to impose a total shutdown is implied, such that further increases in union density are not to be equated with higher union wage gaps.

\section{Union Wage Gap Curves by Component of Total Earnings}

The total monthly compensation of a worker can be divided into several components. In Portugal, a fraction of a worker's compensation is a function of working time and the work schedule. Thus, the worker receives a fixed monthly wage (the base wage), namely monthly compensation for the normal 
work period. As appropriate, there are also overtime or shift payments. Beyond these components, workers are commonly entitled to fringe benefits. For example, by law a worker is entitled to a fixed daily meals allowance for each day worked. Additionally, there are other more diffuse regular fixed fringe benefits, which may include job seniority bonus (diuturnidades), employer contributions to employees' private pension plans, health insurance, and even child allowances. On top of regular compensation, workers may also be entitled to productivity bonuses that are ordinarily distributed once a year.

Taking the year 2010 and using the methodology used previously, we may construct a series of union wage gap curves for the various components of a worker's regular compensation. Five such additional curves are constructed in Figure 2. Our breakdown of monthly compensation distinguishes between the base wage, overtime pay, shift pay, the meals subsidy, and other regular fringe benefits received. The wage gap for the total wage, described earlier, is broadly supported by the pattern of differentials obtaining for each component of the worker's regular compensation, but it is elevated in the case of fringe benefits that are not related to working time. In a material sense, these payments are the same for a sizable share of workers in the firm, irrespective of their job title. For example, the meals subsidy is often of equal amount per worker, while the tenure-related payments that represent a major share of the other regular benefits are more a function of tenure than of job-title.

(Figure 2 near here)

As far as the share of compensation linked to working time and the work schedule is concerned, it is noticeable that these contribute to a reduction in the union wage gap soon after or even before union density extends to the a majority of the workforce. By comparison with the fringe benefits unrelated to working time, this latter tendency suggests a union preference away from working-time related compensation toward non-working-time related compensation. Thus, when capable of exerting a meaningful influence on the firm's compensation policy, unions seemingly prefer to acquire sizable wage differentials in those components of compensation that by default are equal for every worker, even as they countenance a reduction of wage gaps in the other components of compensation. This finding is consistent with the canonical evidence that wage differentials for variables such as age and education are smaller in more heavily unionized environments.

Furthermore, this reshuffling of the firm's compensation policy is likely not unrelated to the tax environment. For the United States, Felix and Hines (2009) have reported that unions and firms take taxation into account in their negotiations, in effect bargaining over the distribution of potential tax savings. Portuguese tax policy has typically favored certain fringe benefits over wages. Even if this more 
favorable tax treatment ${ }^{14}$ has been diluted in the present crises, it has served to pull the bargaining parties in a direction allowing for tax optimization on the part of firms. Therefore, as Rees (1968) noted long ago, unionization and preferable tax treatment are engines behind the increasing share of private supplements in workers' compensation.

\section{The Sources of the Union Wage Gap for Total Earnings}

The sizable union wage gap for total earnings that we have estimated constitutes an average differential between the wages of two observably identical workers in two observably identical firms with distinct levels of unionization. A key question concerns the potential sources of the unobserved heterogeneity behind these differentials. Put differently, it is relevant to determine precisely which dimensions of the market are 'perturbed' to create these gaps between matches of observationally equivalent workers and firms. We next consider the extent to which the perturbations reflect unionism's influence on firms' compensation policies, differences in the assignment of job titles to workers according to the level of unionism, and even differences in the ability of workers for different levels of union membership.

Theoretically, the conditional influence (i.e. accounting for observables) of unions on earnings compensation can arise from other sources, but as a practical matter we find that after accounting for firm, worker, and job title fixed effects the portion of the union wage gap remaining to be explained is vestigial. This is the case for both the linear approach and the fitted union wage gap curve. Our focus in decomposing the union wage gap is therefore upon the contributions of each of these three sources of unobserved heterogeneity. In what follows, the major difference between the two approaches resides in the flexibility of the estimates, offering improved estimation of the union wage gap curve vis-à-vis the linear approach.

Results for the Gelbach decomposition of the linear specification coefficient are first summarized. The estimates contained in Table 2 suggest that the union wage gap, of some 14.2 log points, is mostly built on a union's perturbation of the firm's compensation policies, and, to a very much smaller degree, on the allocation of worker characteristics. In a fully unionized firm, irrespective of the observable characteristics in the model, the unobserved characteristics of workers, and given an equal process of jobtitle assignment, workers receive an extra 11.9 log points of compensation than in a non-unionized firm. Further, there is evidence that beyond the premium stemming from the more generous compensation policies of unionized firms, workers are also not chosen independently of the union density of the firm. Controlling for observable characteristics, the compensation policy of the firm, and the process of job-title attribution, workers working in a fully unionized firm have a permanent compensation for their unobserved characteristics that is some 1.4 log points higher than for a non-unionized firm. These

\footnotetext{
${ }^{14}$ For example, the meals subsidy is not taxed below a certain daily rate while private health insurance plans and private retirement schemes that complement social security are subject to special exemptions.
} 
unobserved (to the researcher) worker characteristics are of course often perceived by the management of the firm, and are conventionally equated with unobserved ability. Finally, we find that the attribution of job-titles process, now accounting for the observed and unobserved characteristics of workers and firms, may be slightly different in a fully-unionized than a non-unionized firm, contributing around $0.8 \log$ points to the estimated union wage gap - an effect that is imprecisely estimated.

\section{(Table 2 near here)}

From Figure 3 it can be seen that the estimates of the Gelbach decomposition of the union wage gap curve broadly confirm the principal result of the OLS approach, namely the leading role reserved for the compensation policies of firms. However, when both sets of results are compared, the decomposition of the union wage gap curve now records a meaningful trade-off between union influence over the compensation policies of the firm and both worker ability and the process by which job titles are assigned, especially once a majority of the workforce is unionized. In fact, the two latter potential sources, and notably the assignment of job titles, are no longer negligible influences. Once again, the limitations attaching to the linearity property are evident, notably in respect of highly unionized firms.

(Figure 3 near here)

\section{The Sources of the Union Wage Gap, Bargained Wages and the Wage Cushion}

The bargained wage is defined as the wage floor under a collective agreement, and thus corresponds to the minimum that a firm is allowed to pay as base wages to a specific worker given that worker's function/job description at the firm. ${ }^{15}$ Ordinarily, the full array of bargained wages in a firm is fully displayed in the wage tables of the applicable collective agreement, namely a set of bargained wages structured according to job-title. For its part, the wage cushion is corresponds to the ratio between the total and the bargained wage. Thus, the logarithm of total compensation is the sum of the logarithms of the bargained wage and the wage cushion. ${ }^{16}$ Therefore, analysis of these components of total compensation allows for a useful partition of the wage into a mandatory part that is imposed through collective bargaining and a voluntary component part that firms may be willing to pay.

Due to the bargaining framework, however, the unions have two natural opportunities to present their demands: at sectoral or industry level and within the firm. While the bargained wage is typically influenced by the actions of the unions at the former level, the wage cushion is likely to be affected by

\footnotetext{
${ }^{15}$ Following the methodology proposed in Cardoso and Portugal (2005), the bargained wage is defined as the mode of the base wage within each year and job-title. Having documented contractual wages for three industries employing around 10 percent of full-time workers in manufacturing and services, these authors show that the mode of the wage distribution of the base wage for each worker category within each collective agreement matches quite well the mandatory floors for each job-title at collective bargaining level.

16 That is, $W_{\text {Total }}=W_{\text {Bargain }} \times \frac{W_{\text {Total }}}{W_{\text {Bargain }}}=W_{\text {Bargain }} \times W_{\text {cushion. }}$. After a logarithmic transformation, $\log \left(W_{\text {Total }}\right)=\log \left(W_{\text {Bargain }}\right)+\log \left(W_{\text {cushion }}\right)$.
} 
realities at the workplace. A useful way to look of this exercise is to think of an artificial situation in which all workers simply collect the bargained wage corresponding to their job titles. This two-layered ability to bargain is shown in our linear specification estimates of the union wage gap for the bargained wage and the wage cushion, summarized in the first row of Table 3. In fact, we report evidence of union wage gaps for both components of total compensation. But they are of distinct sign: the estimated gap in the case of bargained wages amounts to 27.2 log points while that for the wage cushion is negative at 13.0 log points. By construction, the sum of these gaps represents the union wage gap indicated for total compensation of $14.2 \log$ points.

\section{(Table 3 near here)}

Similar results are obtained when union wage gap curves are estimated. Here the union wage gap curve of the bargained wage attains levels of more than 35 percent when the large majority of the workforce is unionized, while the corresponding curve of the wage cushion declines up to minus 20 percent. The union wage gap curves estimated for the bargained wage and the wage cushion reinforce the evidence that unions have a growing effect on compensation policies until the large majority of workers are unionized, after which point that ability is curtailed. The results are summarized in Figure 4.

(Figure 4 near here)

The sizable union wage gap of the bargained wage is not surprising, as unions naturally seek to lock in a significant share of their gains through mandatory dispositions of the collective agreements. In the case of highly unionized firms, unions may be expected to place greater emphasis upon a higher bargained wage. In response, firms may reduce the wage cushion, by seeking an "approximation” of the level of the base wage and the level of the bargained wage ${ }^{17}$ and/or they may also reduce or increase in smaller proportion the regular flexible component (i.e. the amount paid above the bargained wage). Observe that in the case of a perfect offset, we should observe a wage cushion gap of -27.2 log points while in the case of a perfect pass-through that gap would be zero. In fact, the wage cushion gap is -13.0 $\log$ points. Accordingly, there is a partial offset of the increase in the mandatory floors on total compensation, as total compensation does not increase by the same proportion as the mandatory floor. Nevertheless, a sizable union wage gap for total compensation remains.

In somewhat greater detail, we see that the Gelbach decomposition of the bargained wage (shown in the second column of Table 3) illustrates the major role of job-title permanent heterogeneity in the

\footnotetext{
${ }^{17}$ The behavior of the union wage gap for the base wage has already been illustrated in Figure 2 (based on the 2010 Relatório Único). In fact, the comparison between the union wage gap for the bargained wage and the union wage gap for the base wage allow us to determine the approximation of both values implying the fall in the union wage gap for the wage cushion. However, as both gaps show, that does not mean that the base wage falls. Rather, it simply implies that the bargained wage (the wage floor) reveals a higher union wage gap than the base wage, verifying a contribution for the compression of the wage cushion.
} 
construction of the union wage gap. Thus, a comparable worker in a highly unionized comparable firm has access to, and is slotted into, a job-title that prescribes a significantly higher bargained wage, thus confirming the idea of the imposition of higher mandatory base wage floors in more highly unionized firms. The situation is even more transparent in Figure 5, where the decomposition is performed over the wage gap curve for the bargained wage, and where the contribution of the job-title component follows closely the path/behavior of the union wage gap. Furthermore, the tiny contribution of worker and firm permanent heterogeneity in the creation of the union wage gap of the bargained wage is reaffirmed. In short, the recorded union wage gap of bargained wage is almost entirely driven by the job-title allocation process, and corresponds to the increase of mandatory base wage floors in more highly unionized regimes.

\section{(Figure 5 near here)}

Gelbach decomposition of the wage cushion allows us to reconcile the influence of unions on the bargained wage on the one hand and their effects on total compensation on the other. In particular, we can estimate the size of the offset in the flexible component of total compensation from setting higher base wage floors, by comparing the effect of the job-title component on the wage cushion and the job-title component on the bargained wage. We can next isolate the effect of unions on the general compensation policies attaching to the flexible component of the total compensation via the firm and worker components of the wage cushion decomposition.

Using the linear procedure (the third column of Table 3), we estimate that the effect of unions on the bargained wage via the job-title mechanism is, in large part, diluted by reason of the regular flexible component of compensation. Specifically, the estimated 24.1 log point differential for the bargained wage, derived from the heterogeneity in the job-title framework, corresponds to a reduction in the wage cushion of $23.5 \log$ points. To a large extent then, firms offset the increase in mandatory wages by decreasing the regular and flexible component of pay, such that the effect of job-title in the union wage gap for total compensation is modest in the extreme. ${ }^{18}$ If no other force were to influence the total compensation union wage gap, the job-title effect on the basis of this linear procedure would be just 0.8 $\log$ points - or a maximum of around 4 percent when the majority of the workforce is unionized, using the union wage gap curve estimates of Figure 3.

However, this is not the entire story, as we have yet to account for the contributions of the worker and firm dimensions. Our estimates reveal that unions are associated with more generous compensation policies at firm level (via the regular flexible components of pay plus the difference between the

\footnotetext{
${ }^{18}$ In the case of a perfect offset, and excluding composition effects, the increase in the job-title component of the bargained wage decomposition would precisely match the decrease in the job-title component of the wage cushion. In that case, a given job-title would see the mandatory component increase and the flexible regular component decrease by the same proportion, leaving total compensation unchanged.
} 
bargained and the base wage) over and above the mandatory floors defined at job-title level. That is, the linear estimate of the contribution of firm permanent heterogeneity to the wage cushion is 10.1 log points, which result underscores the relation between highly unionized environments and more favorable compensation policies even in the flexible regular component paid at firm level. Not only do more highly unionized firms tend to have a higher share of their workers' base wages settled through collective agreement, but they also embrace more generous compensation policies over and above those mandatory minima. Indeed, it is this latter effect that is the main driver behind the wage differentials in total compensation, given that worker permanent unobserved heterogeneity plays a minuscule role. The Gelbach decomposition applied to the union wage gap curve of the wage cushion, depicted in Figure 6, confirms these stylized ideas.

\section{(Figure 6 near here)}

In a nutshell, compensation in more unionized environments has a more sizable mandatory component - via a higher bargained wage - that comes at the cost of a reduction in discretion at firm level, with only a partial, albeit nonetheless material, 'undoing' of the differential in bargained wages. This partial offset is achieved along the flexible components of compensation which record on average lower levels of wage differentials, implying a fall in the wage cushion. Although subject to this process of offset, more highly unionized firms tend to be more generous on the flexible components of compensation, and on base wages, confirming our earlier results on the estimation of union wage gaps by type of compensation. On net, therefore, a sizable union wage gap in total compensation is maintained.

\section{Causality between Unionism and Wage Differentials}

The issue of causation attends most discussions of the union premium by reason of omitted variable bias and the endogeneity of unionization - often accompanied by concerns over the representativeness of the study population. Our own analysis is not free of aspects of this controversy since the evidence of sizable wage premia does not establish a causal link between bargaining power and wages. There is, then, an issue of reverse causality if unions seek out firms with more generous compensation policies to begin with or locate in those firms that are more permeable to unions' demands. More specifically, ambiguity is not lacking from the firm fixed effect, and even if no such issues arise in the case of worker heterogeneity or (to a lesser extent) job title fixed effects as sources of the union wage gap their contributions are secondary. Accordingly, although we know a great deal about union influence in constraining firms in their design of wage policies from our analysis of the decomposition of total compensation and the wage gap, we are perhaps on firmest ground in treating the firm-fixed effect component as establishing an upper bound to the true effect of unions on compensation from this source. That said, we feel no need to cede ground to the claim that a regression discontinuity approach even if it were possible in the Portuguese case (where representation elections do not take place) would provide more convincing/much 
lower estimates of the union premium. Here we take comfort in the finding by Lee and Mas (2012) to the effect that cumulative abnormal returns in union election wins are much more negative (i.e. the stock market effect is more severe) where the vote share in support of a union is strong. That said, further investigation of the role of the wage policies of the firms is warranted along the gradient of the wage gap profile.

\section{Robustness Issues}

\section{The Role of Match Quality}

The recent literature has devoted much attention to the issue of the match between firms and workers, in a discussion that extends well beyond the effect of the heterogeneity of each dimension. This growing line of research (for a survey, see Torres et al., 2015) focuses on the possibility of assortative matching, with higher quality workers forming a match with high-paying firms. Permanent synergies (or, conceivably, antagonisms) may arise in these “marriages," resulting in a mismeasurement of worker and firm heterogeneity if these are taken separately. Controversy has arisen as to whether assortative matching can be directly revealed in a wage equation, but this disputation does not affect the construction of the union wage gap since it is defined as the wage differential between two observably identical workers in two observably identical firms, and is constructed without fixed effects. Nevertheless, it remains germane whether the degree of unionization at firm level affects the match between workers and firms, and thereby leads to mismeasurement of the components of the union wage gap for total compensation.

To tackle this issue, we next perform a Gelbach decomposition in which the components are reduced to job-title heterogeneity and match heterogeneity, the latter functioning as a composite term combining worker $\left(\alpha_{i}\right)$ and firm fixed effects $\left(\lambda_{f}\right)$ and their interaction $\left(\tau_{i f}\right)$. Therefore, equation (3) becomes:

$$
y_{i, t}=\boldsymbol{x}_{i, t}^{\prime} \widetilde{\boldsymbol{\beta}}+U d_{f} \tilde{\gamma}+\mu_{i f}+\theta_{j}+\delta_{t}+\varepsilon_{i, t},
$$

where $\mu_{i f}$ is the match fixed effect $\left(\mu_{i f}=\alpha_{i}+\lambda_{f}+\tau_{i f}\right)$. In this case, the main result of the Gelbach decomposition becomes:

$$
\hat{\gamma}-\widehat{\tilde{\gamma}}=\widehat{\gamma_{l f}}+\widehat{\gamma_{\theta}}
$$

The same principle may be applied to the decomposition of the union wage gap curves, where the full-specification model, comparable to equation (7), becomes

$$
y_{i, t}=\boldsymbol{x}_{i, t}^{\prime} \widetilde{\boldsymbol{\beta}}+\widetilde{\vartheta_{u}}+\mu_{i f}+\theta_{j}+\delta_{t}+\varepsilon_{i, t},
$$

while the decomposition holds as 


$$
\hat{\vartheta}-\hat{\tilde{\vartheta}}=\widehat{\vartheta_{l f}}+\widehat{\vartheta_{\theta}}
$$

The results of the Gelbach decomposition for both the linear approach and the union wage gap curve are summarized in Table 4 and Figure 7, respectively.

(Table 4 and Figure 7 near here)

Theoretically, with the inclusion of the job match term, the potential sources of the union wage gap include not only the job-title and worker and firm components but also the quality of the match between worker and firm. Econometrically, the inclusion of this worker-firm match fixed effect implies the joint estimation of the last three of the above potential sources of the union wage gap. This in turn requires a specific means of comparing the estimates from the standard approach and this new approach in recognition of the fact that the inclusion of firm, worker and firm-worker fixed effects is not feasible by reason of the collinearity among those variables. ${ }^{19}$

Given this econometric issue, an adequate way to make a comparison between the standard methodology and an exercise seeking to account for the worker-firm match is via an analysis of that portion of the union wage gap that remains to be explained after partialing out the explicitly considered sources. This is precisely the realm of the of the full model coefficients; namely, specifically, the $\widetilde{\vartheta_{u}}$ term in equation (7) for the standard decomposition and in equation (12) for the decomposition including the worker-firm match fixed effect. That is to say, the change in the joint capacity of the explicit sources in explaining the union wage gap is due to the inclusion of new sources: in this exercise, the quality of the worker-firm match. Everything else equal, the change recorded in the full model coefficient will fully capture the contribution of the worker-firm match quality to the union wage gap.

Specifically, in the case of the linear approach the change in the full model coefficient, when comparing the standard linear decomposition (Table 2) and the decomposition including the match term (Table 4) is around $0.3 \log$ points, which value will bound the true contribution of the change in the quality of the match to the union wage gap. Similarly, the graphical representation in Figure 8 of the curves of the full model coefficients corresponding to equations (8) and (12) confirms this finding. Vulgo: there is no obvious indication that assortative matching plays a meaningful role in accounting for the union wage gap in total compensation in contrast to its role in the explanation of earnings variation more generally.

(Figure 8 near here)

\footnotetext{
${ }^{19}$ For a detailed discussion about how to deal with this issue, see Figueiredo, Guimarães, and Woodward (2014) and Raposo, Portugal, and Carneiro (2014) .
} 


\section{One-Step Estimation 2010-2013}

In a different exercise, we next check for the robustness of the estimation of the worker, firm, and job-title fixed effects, the estimates of which have a basis in the auxiliary regressions described earlier. For both settings, this initial procedure required the estimation of fixed effects in an equation that eschewed the use of union density as a control. The approach had the advantage of using the entire dataset to estimate the fixed effects along the worker, firm, and job title dimensions (thus reducing the impact of limited mobility bias), but at the cost of not controlling for union density, which is a time-varying argument. To repeat, the motivation was to take advantage of a much longer time span to estimate the three fixed effects, information on union density in the Relatório Único only covering the years 2010-2013. In order to check the validity of this choice in the linear framework, we now estimate equation (4) for the years 2010-2013 in a single step (i.e. without the prior estimation of the worker, firm and job-title fixed effects) over an interval for which we have consistent data for the entire set of variables used in the model, including of course information on firm-level union density. We proceed in the same manner in respect of equation (7).

The results of the respective Gelbach decompositions, based on the full models estimated in this revised procedure, are contained in Table 5 and Figure 9. The new evidence largely comports with the standard results presented previously. ${ }^{20}$ In particular, the firm component continues to dominate and is subject to only minor changes vis-à-vis the standard estimates (cf. Tables 3 and 5). For its part, however, the worker component records some differences that become more pronounced in the decomposition of the union wage gap curve (cf. Figures 3 and 9). This latter result is not surprising because estimation of the worker fixed effect in this revised framework is obtained on the basis of very few elements in each set, given the reduced timeframe included in the estimation. Specifically, each worker appears at most four times in the dataset, and as practical matter a substantial number of workers do not work in some of the sampled years. In consequence, the worker fixed effect becomes more sizable, taking on some of the impact previously attributed to the job title component. Nevertheless, the stylized facts obtained from our standard estimation are again very largely confirmed in this revised estimation.

(Table 5 and Figure 9 near here)

\section{Conclusions}

This paper offers the first definitive estimates of the union premium or union wage gap for Portugal, using a linear and nonlinear regression framework. In a situation where approximately 90 percent of workers are covered by collective agreements but only 11 percent of them belong to unions, the key union indicator is union density at firm level. We provide estimates of the union wage gap for total monthly

\footnotetext{
${ }^{20}$ The computed union wage gap is now slightly different because it is obtained from a different connected set.
} 
earnings, the bargained wage, and the wage cushion. We also investigate the union wage gap by component of compensation, distinguishing between the base wage, regular wage supplements, and working-time related payments. Having provided estimates of the various wage gaps, the second key contribution of the paper is to consider their sources. Our high dimensional three-fixed effects model considers the contribution of worker productivity, the occupational distribution of workers, and the wage policies of firms to the wage gap. That is, the analysis accommodates worker heterogeneity, job title heterogeneity (as manifested in union workers receiving/ being assigned 'elevated' job titles), and unionized firms having to adjust their compensation policies and human resources practices in response to union bargaining power. Central to our being able to establish the relative importance of the sources of the union wage gap, apart from the crucial importance of large matched employer-employee data sets and the deployment of sophisticated econometric techniques, is Gelbach's (2016) decomposition which is based on the formula for omitted variable bias.

What do we find? In the first place there is evidence of a fairly substantial union premium. The union wage gap for total weekly earnings is increasing in firm-level union density until around 70 percent of the workforce is organized, when the premium tops out at approximately 20 percent and thereafter declines modestly. There is also the suggestion that, with the growth in union density, comes an increasing substitution for fringes for working-time related compensation in supplementing the base wage, which development is likely to be attractive to both sides of the bargaining table on tax-related grounds. Decomposition reveals that the firm fixed effect - namely, a perturbation by unionism of a firm's compensation policies - dominates.

Analysis of the bargained wage and the wage gap cast further light on the union premium. In the first place, the bargained monthly wage exhibits a peak union premium almost double that of total monthly earnings, and not surprisingly this is the result of the job-title component given the nature of Portuguese collective bargaining which sets the minima that firms can pay in the form of a base wage to a specific worker given that worker's job description at the firm. (A necessary observation here is that sectors may be said to be characterized by the union density of their constituent firms, highly unionized firms populating highly unionized sectors). But bargaining also occurs at the firm level and this ability is reflected in the gap between the bargained wage and total earnings, namely the wage gap. That unions bargain at local level is revealed in the analysis of the components of total earnings: they enjoy premia in base wages, wage supplements, and indeed working time related pay. But the association between union density and the cushion per se is in fact negative, and is increasing in absolute magnitude with union density. This does not mean that the wage premia secured largely at sectoral level are undone at local level, but rather that the premia secured for other than the bargained wage are smaller. This is made clear in our decomposition of the bargained age and the wage cushion. That said, firms do offset to some 
degree the increase in bargained wages by reducing the flexible components of compensation (as has been noted in the research literature), but once we account for worker and firm heterogeneity union firms are again shown to have more generous compensation policies even in the margins where firms have some room of maneuver to set wages.

In a final exercise, we sought to establish whether our results might be contaminated by mismeasurement of the components of the union wage gap by reason of neglecting job match considerations attendant upon assortative matching (i.e. high productivity workers aligning themselves with high productivity firms), or from the specification of our base estimating equation which did not control for the time varying nature of union density because of the need to estimate the three fixed effects with suitable precision. Neither reservation proved material for total compensation. First, in combining worker and firm fixed effects to allow for their interaction, our decomposition analysis showed that the joint effect differed imperceptibly from the sum of their separate individual effects in the standard estimation. Second, in estimating our models over just four years of data (rather than twenty-four years), the basic result concerning the dominance of the firm fixed effect in total compensation was strongly confirmed, even if the role of worker heterogeneity evinced some instability; each worker appearing a maximum of four times in the dataset, and often less than that, and in the process contaminating the impact of the job-title effect.

The bottom line of this exercise is that we have (a) used a novel procedure to establish the union premium in a regime where almost all workers are covered but few are unionized, (b) provided a unique attribution of that differential to three types of heterogeneity that left almost no room for alterative explanations of wage variation, and (c) offered an internally consistent set of results for bargained pay, total earnings, and the wage cushion at the same time as finding support for the emerging consensus in the wider wage determination literature of the importance of the wage policy of the firms. 


\section{References}

Addison, John T., Pedro Portugal, and Hugo Vilares. 2015. "Unions and Collective Bargaining in the Wake of the Great Recession.” IZA Discussion Paper No. 8943. Bonn: Institute for the Study of Labor.

Cardoso, Ana Rute, and Pedro Portugal. 2005. "Contractual Wages and the Wage Cushion under Different Bargaining Settings.” Journal of Labor Economics 23(4): 875-902.

Cameron, Colin A., and Pravin K. Trivedi. 2005. Microeconometrics. Methods and Applications. Cambridge: Cambridge University Press.

Carneiro, Anabela, Paulo Guimarães, and Pedro Portugal. 2012. "Real Wages, and the Business Cycle: Accounting for Worker, Firm, and Job Heterogeneity." American Economic Journal: Macroeconomics 4(2): 133-152.

Raposo, Pedro S., Pedro Portugal, and Anabela Carneiro. 2014. "Wage Losses of Displaced Workers: the Reallocation of Workers into Firms and Job Titles.”Unpublished paper.

EurWORK. 2013. "Dramatic Decline in Collective Agreements and Worker Coverage." Dublin: European Foundation for the Improvement of Living and Working Conditions. Available at: http://eurofound.europa.eu/observatories/eurwork/articles/industrial-relations/dramatic-decline-incollective-agreements-and-worker-coverage.

EurWORK. 2014. "Portugal: Decline in Collective Bargaining Reaches Critical Point.” Dublin: European Foundation for the Improvement of Living and Working Conditions." Available at: http://www.eurofound.europa.eu/observatories/eurwork/articles/working-conditions-industrial-

Farber, Henry S. 1986. “The Analysis of Union Behavior.” In Orley Ashenfelter and Richard Layard (eds.), Handbook of Labor Economics, Volume 1, Amsterdam: North-Holland, pp. 1039-1089.

Frandsen, Brigham R. 2102. "Why Unions Still Matter: The Effects of Unionization on the Distribution of Employee Earnings." Unpublished Paper, Massachusetts Institute of Technology. Available at: http://www.ewi-ssl.pitt.edu/econ/files/seminars/120224_sem_Brigham\%20Frandsen.pdf

Felix, R. Alison, and James R. Hines. 2009. “Corporate Taxes and Union Wages in the United States.” NBER Working Paper No. 15263. Cambridge, MA: The National Bureau of Economic Research.

Figueiredo, Octávio, Paulo Guimarães, and Douglas Woodward. 2014. "Firm-Worker Matching in Industrial Clusters.” Journal of Economic Geography 14(1): 1-19.

Gelbach, Jonah B. 2016. “When Do Covariates Matter? And Which Ones, and How Much?” Journal of Labor Economics (Forthcoming.). Available at SSRN: http://ssrn.com/abstract=1425737 or http://dx.doi.org/10.139/ssrn.1425737

Guimarães, Paulo, and Pedro Portugal. 2010. "A Simple Feasible Procedure to Fit Models with HighDimensional Fixed Effects.” Stata Journal 10(4); 628-649.

Lee, David S., and Alexandre Mas. 2012. "Long-Run Impacts of Unions on Firms: New Evidence from Financial Markets.” Quarterly Journal of Economics 127(1): 333-378.

Martins, Pedro S. 2014. "30,000 Minimum Wages: The Economic Effects of Collective Bargaining Extensions.” IZA Discussion Paper No. 8540. Bonn: Institute for the Study of Labor. 
Palma Ramalho, Maria do Rosário. 2013. "Portuguese Labor Law and Industrial Relations during the Crisis.” Working Paper No. 54.Geneva: International Labor Office.

Rees, Albert. 1060. New Measures of Wage-Earner Compensation in the United States, 1914-1957. New York: 1st Edition Books.

Schulten, Thorsten. 2013. "The Troika and Multi-Employer Bargaining - How European Pressure is Destroying National Collective Bargaining Systems.” Available at: http://www.socialeurope.eu/2013/06/the-troika-and-multi-employer-bargaining/

Schulten, Thorsten, and Torsten Müller. 2013. “A New European Interventionism? The Impact of New Economic Governance on Wages and Collective Bargaining. In Social Developments in EU 2012, edited by David Natali and Bart Vanhercke, pp. 181-213. Brussels: European Trade Union Institute and the European Social Observatory.

Torres, Sónia, Pedro Portugal, John T. Addison, and Paulo Guimarães. 2015. "The Sources of Wage Variation: A Three-Way High-Dimensional Fixed Effects Regression Model.” Unpublished Paper, University of South Carolina. 


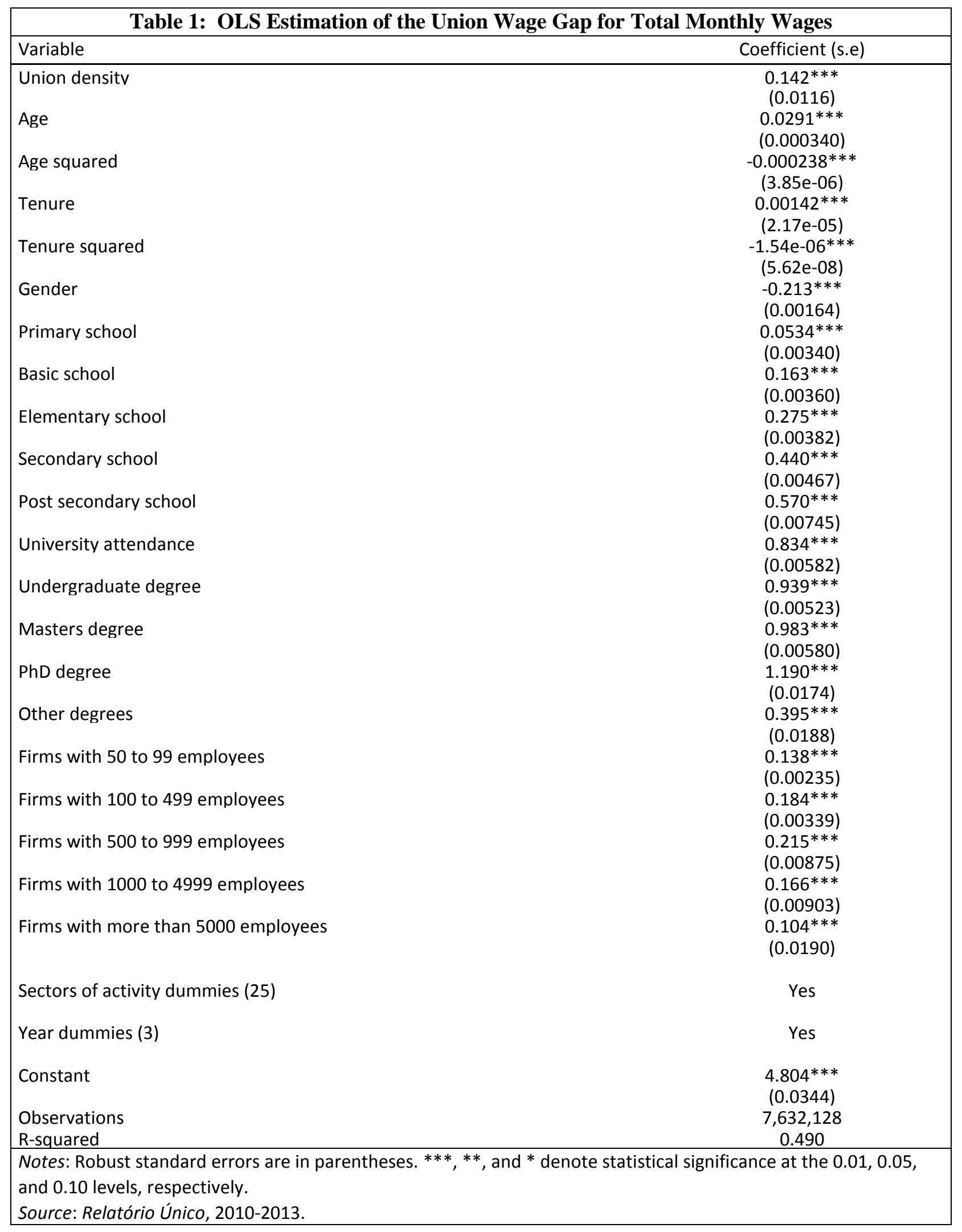




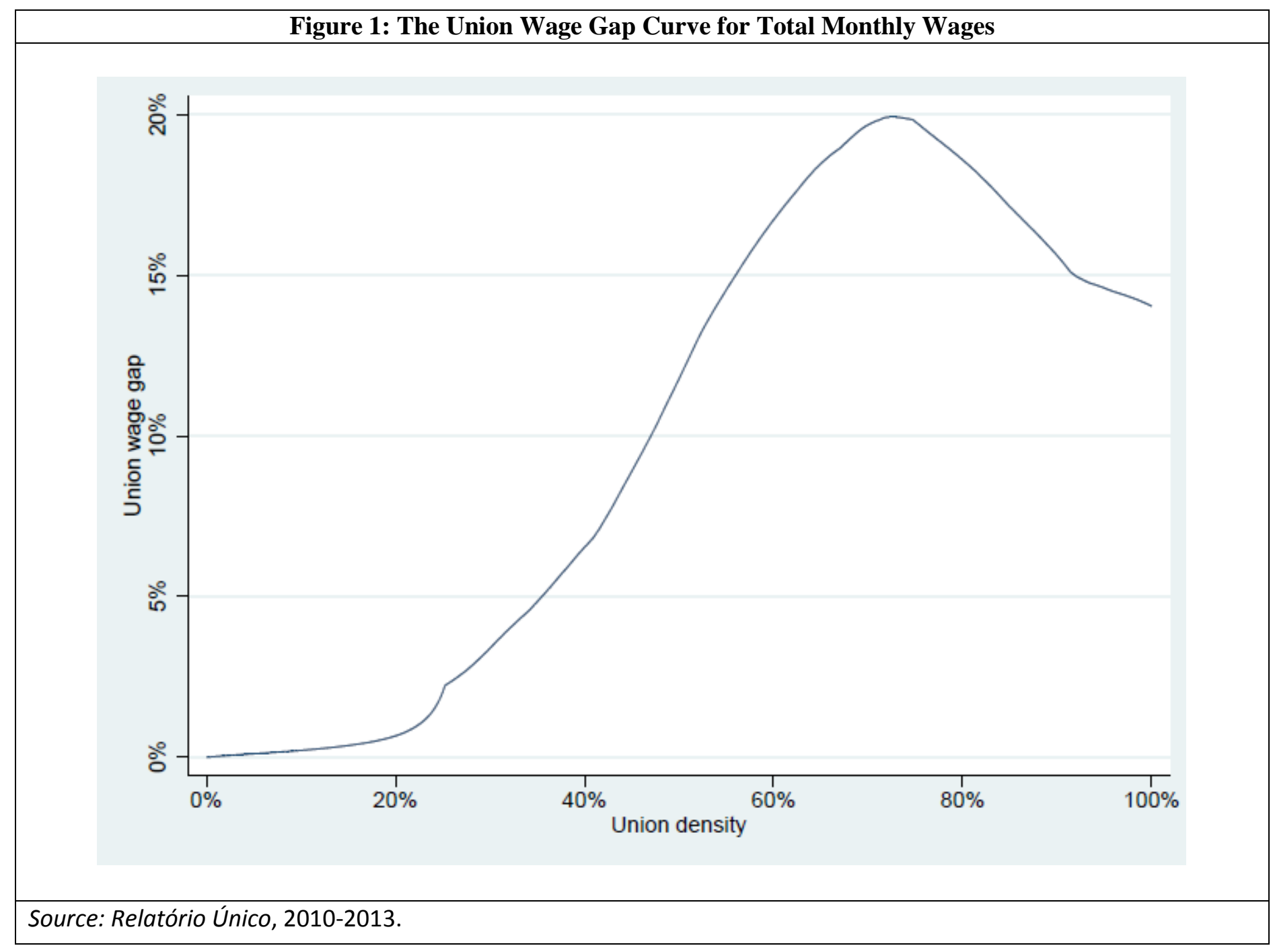




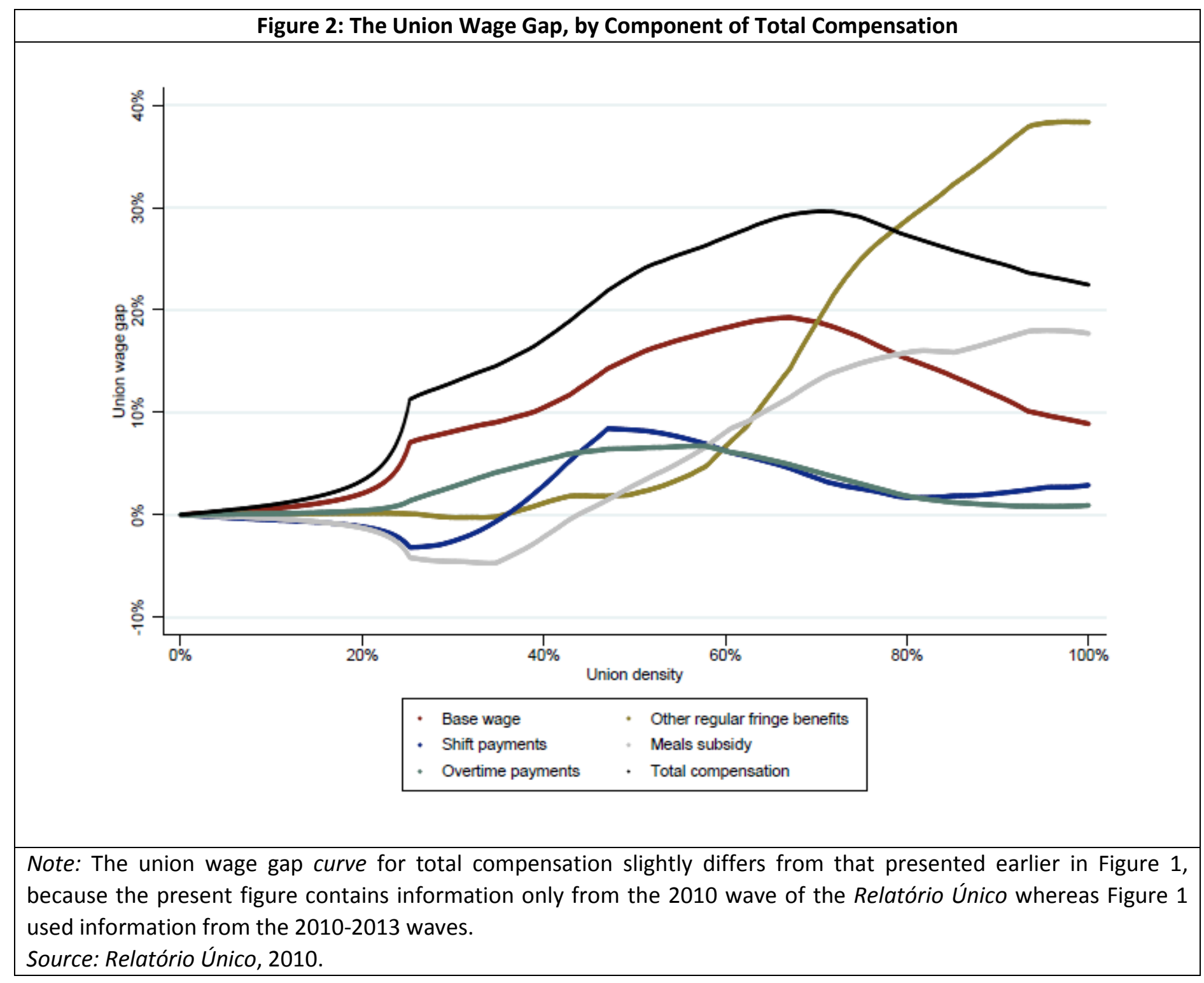




\begin{tabular}{|lc|}
\hline \multicolumn{2}{|c|}{ Table 2: The Conditional Decomposition of the OLS } \\
Estimation of the Union Wage Gap for Total Compensation \\
\hline Variables & Estimates \\
\hline & $0.142^{* * *}$ \\
Estimated Union Wage Gap & $(0.0116)$ \\
& $0.0136^{* * *}$ \\
Worker FE & $(0.00483)$ \\
& 0.00802 \\
Job Title FE & $(0.00604)$ \\
& $0.119^{* * *}$ \\
Firm FE & $(0.00699)$ \\
& 0.00143 \\
Full model coefficient & $(0.00356)$ \\
\hline & Notes: Decomposition based on Gelbach (2016). The base model \\
includes as regressors a quadratic term in age, a quadratic term in \\
tenure, schooling dummies (10), a gender & dummy, firm size \\
dummies (5), and sector dummies (25). & \\
Sources: Quadros de Pessoal 1986-2009; Relatório Único 2010- \\
2013.
\end{tabular}




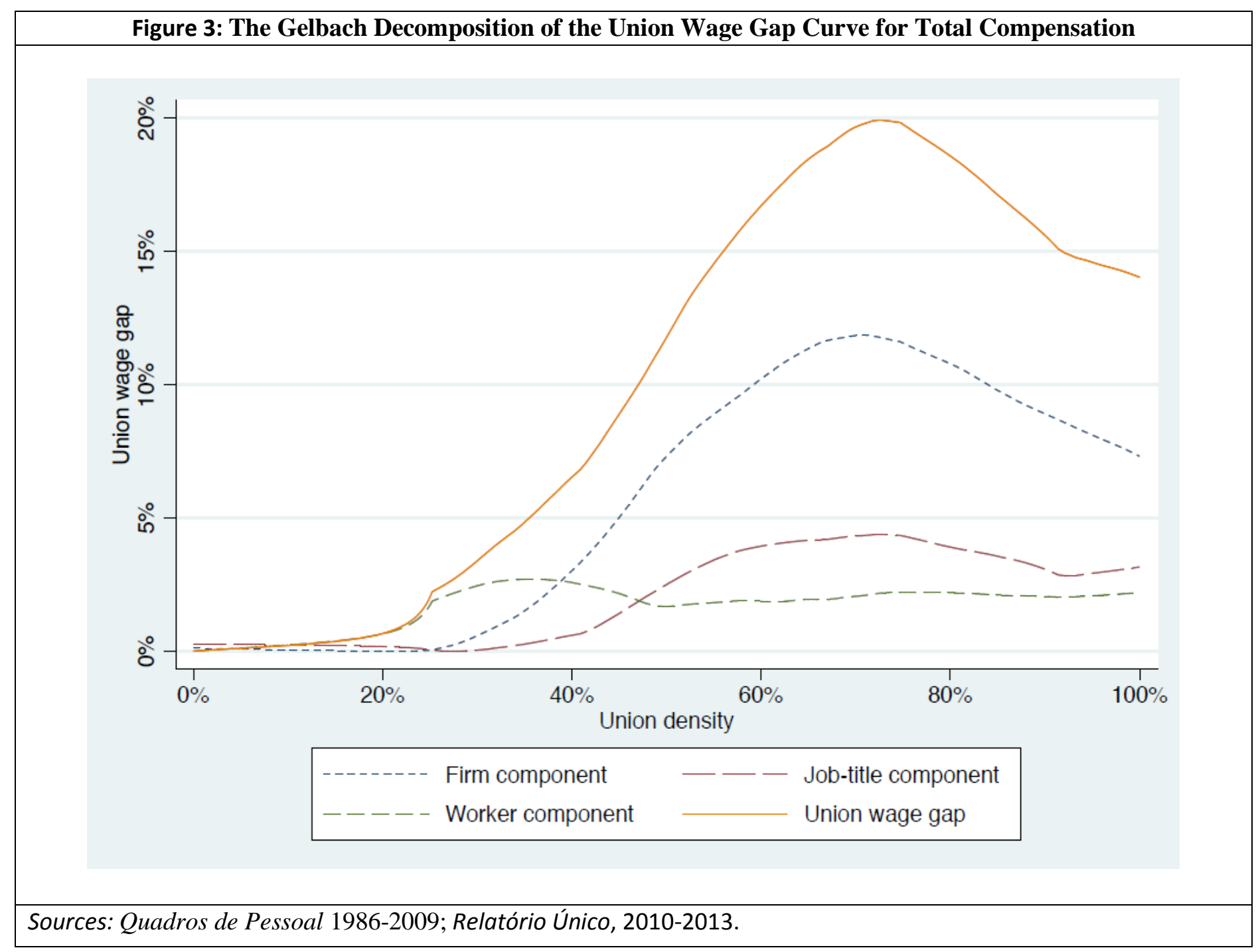




\begin{tabular}{|c|c|c|c|}
\hline Variables & Total Compensation & Bargained wage & Wage cushion \\
\hline Estimated Union Wage Gap & $\begin{array}{c}0.142^{* * *} \\
(0.0116)\end{array}$ & $\begin{array}{c}0.272^{* * *} \\
(0.0153)\end{array}$ & $\begin{array}{c}-0.130 * * * \\
(0.0127)\end{array}$ \\
\hline Worker FE & $\begin{array}{c}0.0136 * * * \\
(0.00483)\end{array}$ & $\begin{array}{c}0.000438 \\
(0.000486)\end{array}$ & $\begin{array}{c}0.0132 * * * \\
(0.00475)\end{array}$ \\
\hline Job Title FE & $\begin{array}{c}0.00802 \\
(0.00604)\end{array}$ & $\begin{array}{c}0.241 * * * \\
(0.0151)\end{array}$ & $\begin{array}{c}-0.235^{* * * *} \\
(0.0135)\end{array}$ \\
\hline Firm FE & $\begin{array}{l}0.119 * * * \\
(0.00699)\end{array}$ & $\begin{array}{c}0.0175 * * * \\
(0.00444)\end{array}$ & $\begin{array}{l}0.101^{* * *} \\
(0.00693)\end{array}$ \\
\hline Full model coefficient & $\begin{array}{c}0.00143 \\
(0.00356)\end{array}$ & $\begin{array}{c}0.0134 * * * \\
(0.00220)\end{array}$ & $\begin{array}{c}-0.00967 * * \\
(0.00394)\end{array}$ \\
\hline
\end{tabular}


Figure 4: The Union Wage Gap Curves for Total Compensation, the Bargained Wage, and the Wage Cushion

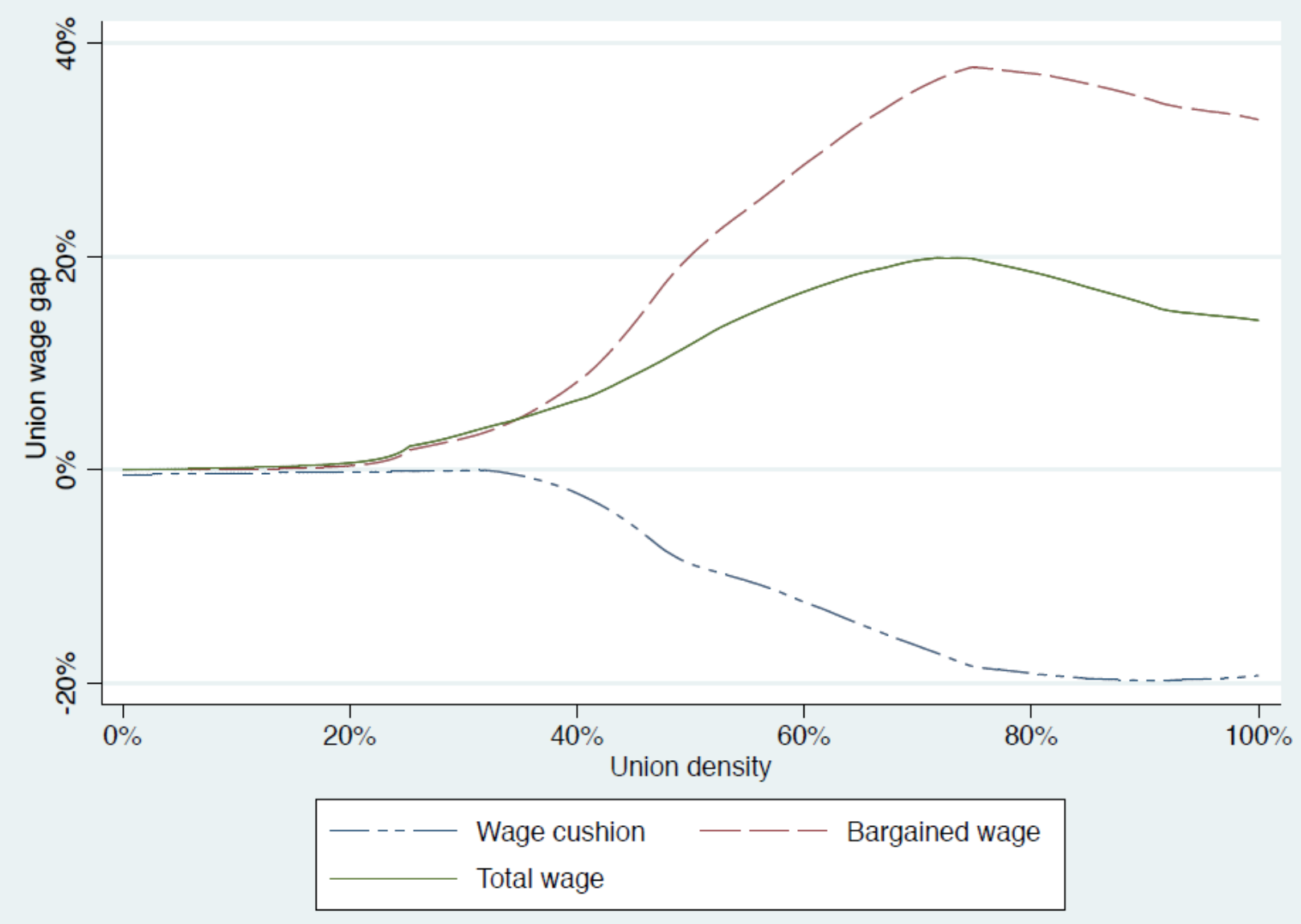

Sources: Quadros de Pessoal 1986-2009; Relatório Único, 2010-2013. 


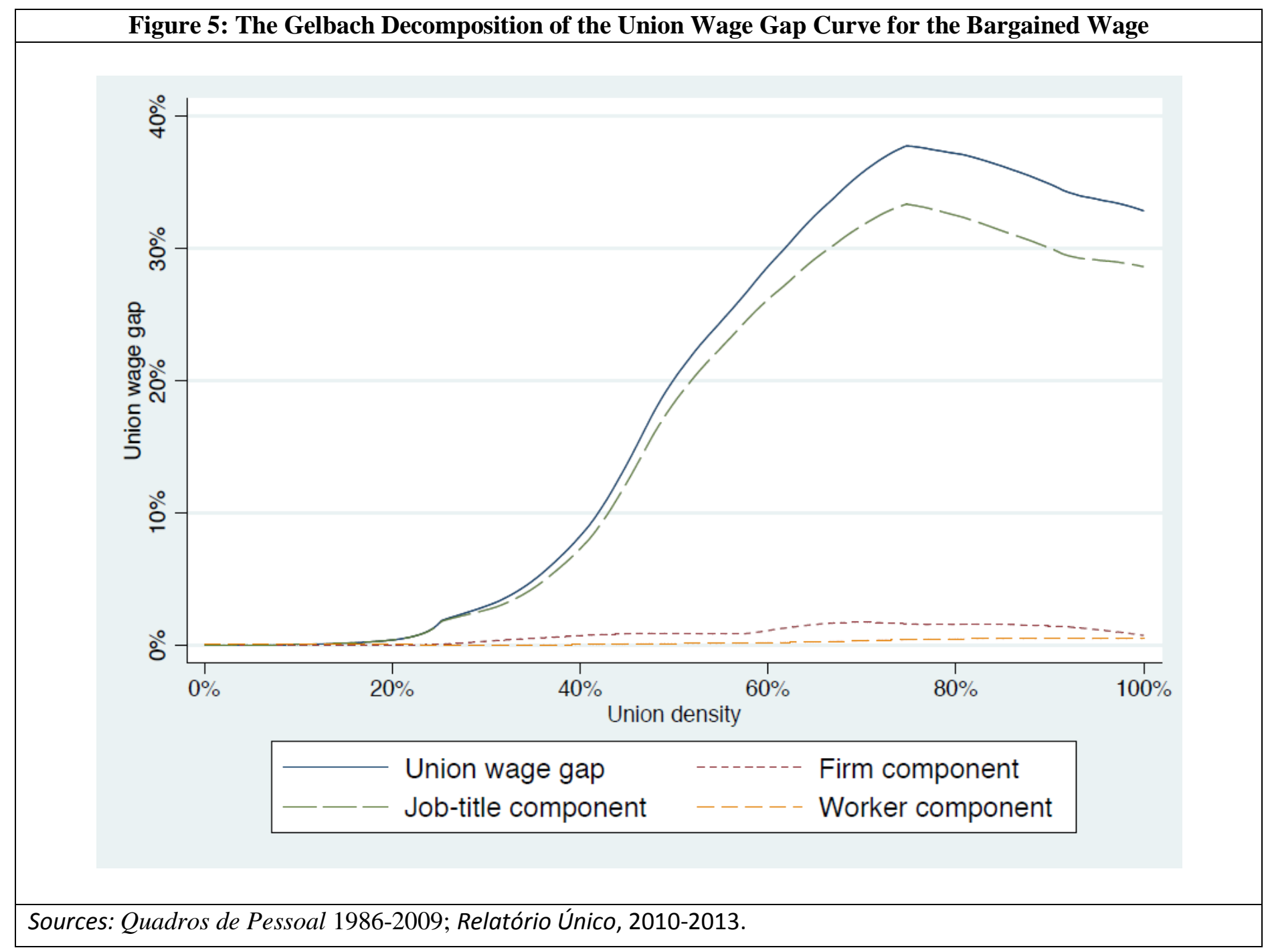




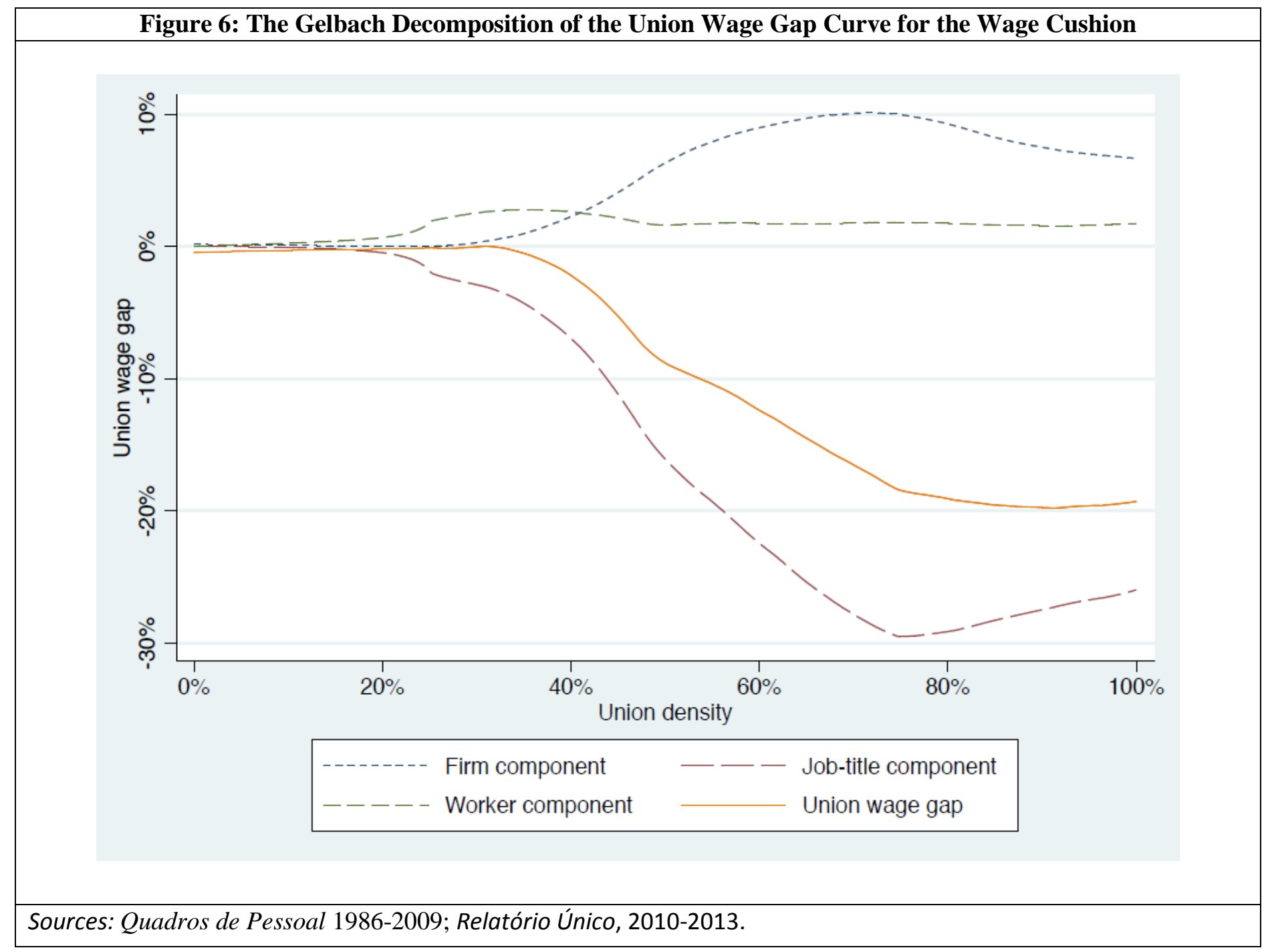




\begin{tabular}{|lc|}
\hline \multicolumn{2}{|c|}{$\begin{array}{c}\text { Table 4: The Conditional Decomposition of the OLS } \\
\text { Estimation of the Union Wage Gap for Total } \\
\text { Compensation, Introducing a Job Match Component }\end{array}$} \\
\hline Variables & Estimates \\
\hline Estimated Union Wage Gap & $0.142^{* * *}$ \\
& $(0.0116)$ \\
Match FE & $0.134^{* * *}$ \\
& $(0.00899)$ \\
Job Title FE & $0.00885^{*}$ \\
& $(0.00518)$ \\
Full model coefficient & -0.00140 \\
& $(0.00330)$ \\
\hline Notes: Decomposition based on Gelbach (2016). The base model \\
includes as regressors a quadratic term in age, a quadratic term in \\
tenure, schooling dummies (10), a gender dummy, firm size \\
dummies (5), and sector dummies (25). \\
Sources: Quadros de Pessoal 1986-2009; Relatório Único 2010- \\
2013.
\end{tabular}


Figure 7: The Gelbach Decomposition of the Union Wage Gap Curve for Total Compensation, Introducing a Job Match Component

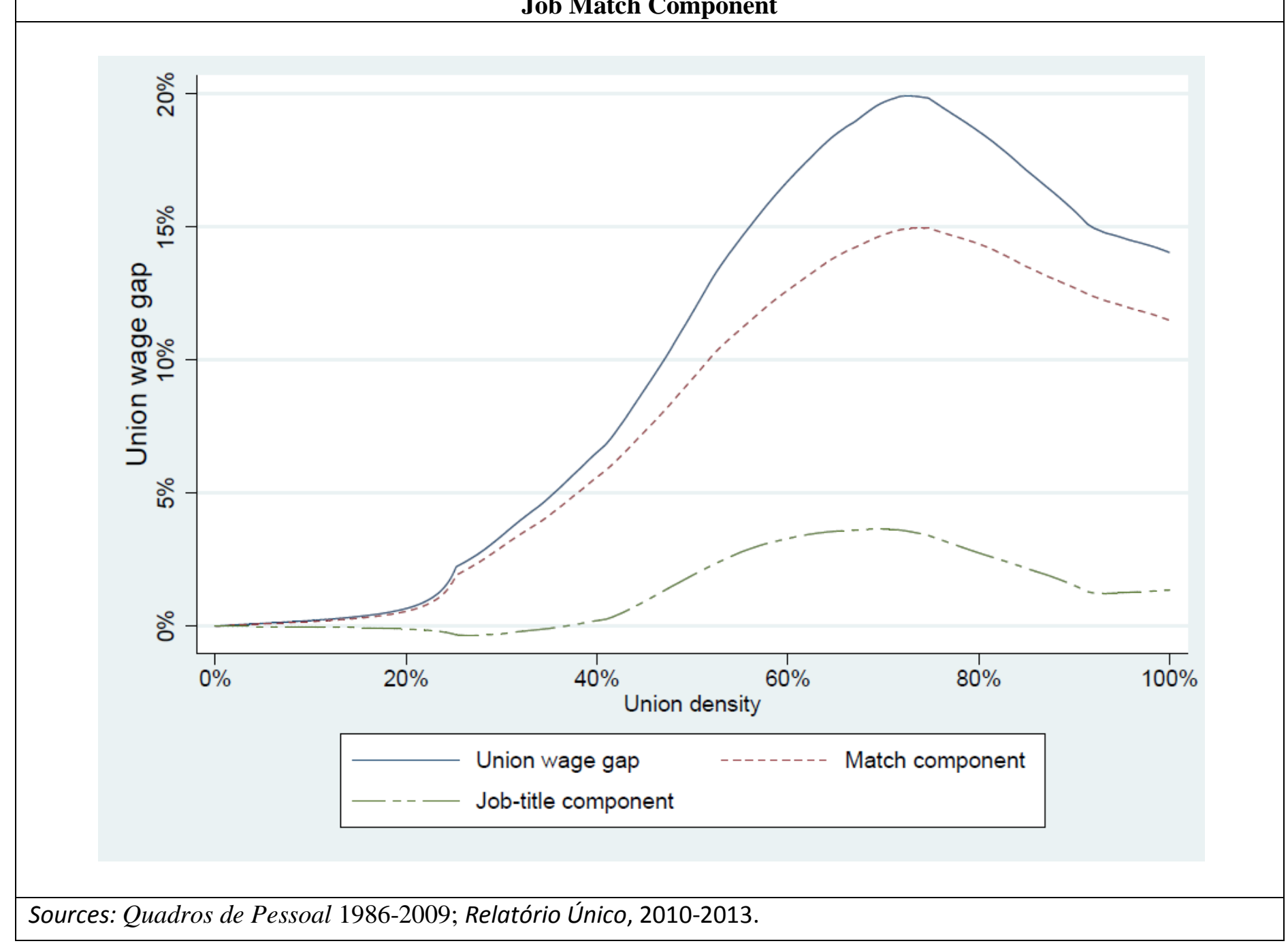




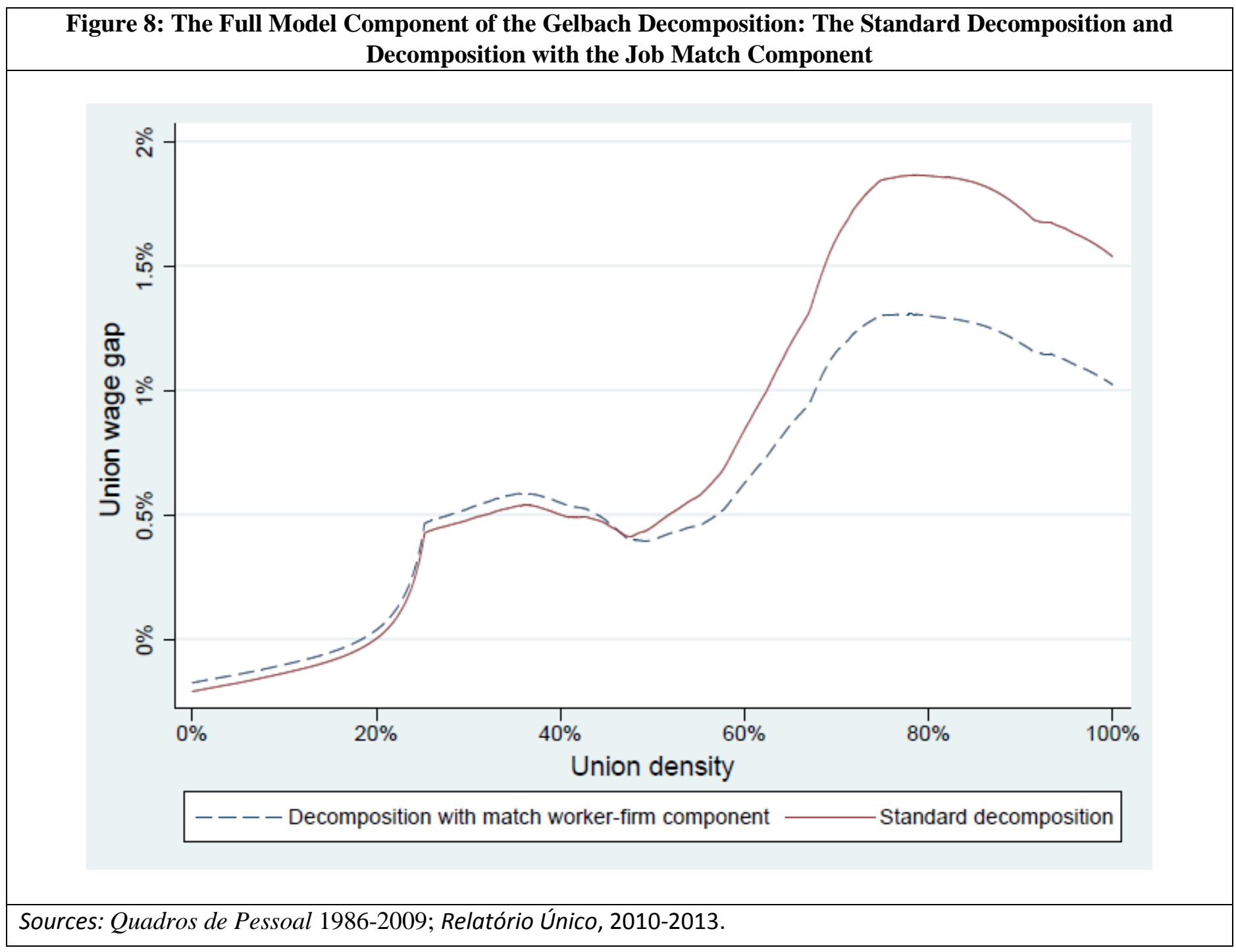




\section{Table 5: The Conditional Decomposition of the OLS}

Estimation of the Union Wage Gap for Total Compensation, with Fixed Effects Estimated Controlling for Union Density

Variables

Estimated Union Wage Gap

Worker FE

Job Title FE

Firm FE

Full model coefficient
Estimates

$0.113^{* * *}$

$(0.0131)$

$0.0262 * * *$

(0.00788)

$0.00305^{* * *}$

$(0.00628)$

$0.0916^{* * *}$

$(0.0104)$

$-0.00778 * * *$

(0.00219)

Notes: Decomposition based on Gelbach (2016). The base model includes as regressors a quadratic term in age, a quadratic term in tenure, schooling dummies (10), a gender dummy, firm size dummies (5), and sector dummies (25).

Source: Relatório Único 2010-2013. 
Figure 9: The Gelbach Decomposition of the Union Wage Gap Curve for Total Compensation, Estimation of Fixed Effects Controlling for a Union Density Fixed Effect.

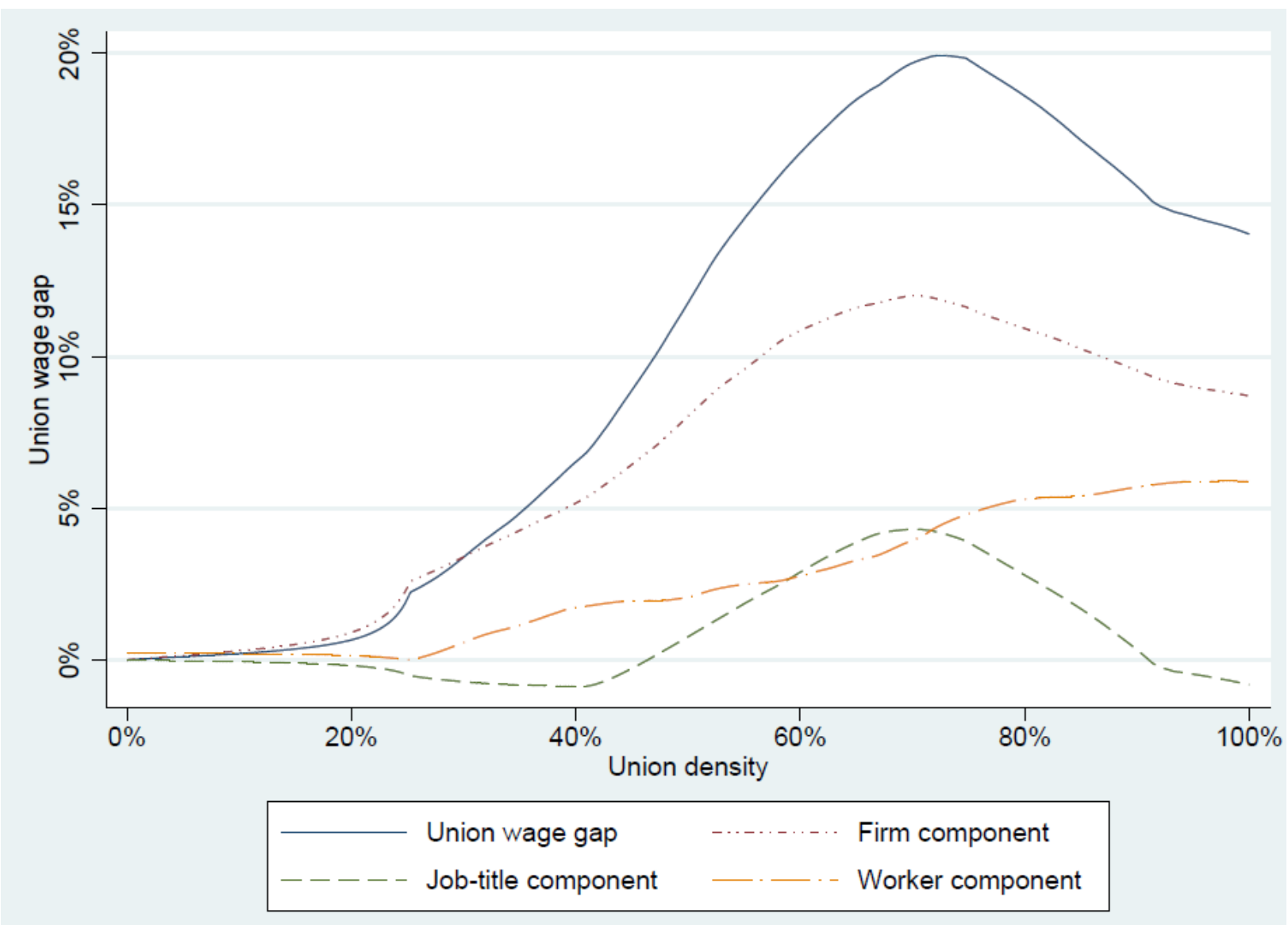

Source: Relatório Único, 2010-2013. 